\title{
Economic Development and Foreign Policy, The Case of Syria 1949-1954
}

Mehmet Osman ÇATI, Department of Political Science and International Relations, Faculty of Economics and Administrative Sciences, Mugla Sitki Kocman University, Turkey; e-mail: osmancati@mu.edu.tr

\section{Ekonomik Kalkınma ve Dış Politika, 1949-1954 Suriye Örneği}

\begin{abstract}
This paper aims to enhance our understanding of the relationship between economic development and foreign policy in Syria in the post-independence period. In this endeavour, Syria has been taken as a state of the global South that was bound to be preoccupied with its condition of underdevelopment, dependence, vulnerability and permeability. Adopting a political economy approach to examine a period of instability marked by three military coups, this paper presents socioeconomic needs of the country as a source of foreign policy and identifies the acquisition of external resources as a key foreign policy objective.
\end{abstract}

Keywords : Economic Development, Foreign Policy, Socio-economic Needs, Resource Gap.

JEL Classification Codes : $\quad$ E60, F35, F52, F54, F63.

\section{Öz}

$\mathrm{Bu}$ çalışmanın temel amacı bağımsızlık dönemi sonrası Suriye'de ekonomik gelişme ile dış politika arasındaki ilişkiyi incelemektir. Bu bağlamda Suriye azgelişmişlik, bağımlılık, dış etkilere açık olmak gibi temel sorunlarını aşmaya çalışan bir küresel Güney ülkesi olarak ele alınmaktadır. Bu çalışma, askeri darbelere sahne olan ve istikrarsızlığın hâkim olduğu beş yıllık bir dönemi ekonomi politik yaklaşımı ile ele alırken ülkenin sosyoekonomik ihtiyaçlarını dış politika kaynakları arasında sunmakta ve yabancı kaynakların elde edilmesini temel bir dış politika amacı olarak sunmaktadır.

Anahtar Sözcükler Ekonomik Gelişme, Dış Politika, Sosyoekonomik İhtiyaçlar, Kaynak Açığı. 


\section{Introduction}

As the Cold War unfolded after the end of the Second World War, the international system was infused with a large number of new states as a result of the decolonisation process. More recently called the states of the 'global South' in recognition of the phenomenon of globalisation, these states have variously been categorised as 'underdeveloped', 'less-developed', 'developing', 'weak', 'third world', 'non-core', or 'periphery’ states (Macfarlane, 1999: 15-33; Morphet, 2004: 517-537). Whatever the label, the primary concerns and problems of these newcomers extended well beyond military and strategic issues to include issues of economic development and dependence, legitimacy, regime survival, identity, and state and nation-building. Yet, since these states possessed few of the capabilities traditionally associated with power politics, their foreign policies were understudied or when studied the inclination was to approach them as rather passive objects of great-power rivalry denying them a purposeful foreign policy of their own.

Therefore this study argues for an inclusive approach that does not confine the contours of enquiry to external military threats and the projection of power abroad. Restrictive views with respect to the delineation of the subject matter fail to address foreign policy concerns of a vast majority of states which count an overwhelming majority of the population of the world as their inhabitants. In many of these states, as it had been the case prior to World War II when they existed as independent entities and during the post-war period once they were free of colonial rule, issues dismissed as irrelevant to international theory have been ascribed a fundamental value.

In what may be taken as a reflection of the pervasiveness of the traditional approach even among the finest scholars of the global South, Volker Perthes, the author of a study of supreme quality on the political economy of post-1970 Syria, found it notable that any discussion existed about Syria's foreign policies in the 1990s. In his view, 'thirty, even 20 years earlier, there was hardly any foreign policy of Syria's own making to deal with' (Perthes, 1995: 5). ${ }^{1}$ In the same vein, according to Malik Mufti, whose work is commendable as an attempt to link the development of state institutions to the development of foreign policy, it was only after Hafiz al-Asad came to power in 1970 that 'Syria's foreign policy grew more "state-like"... as a strategic arena in which to gain influence and frustrate foes' (Mufti, 1996: 231).

Although the international relations and foreign policies of the actors in the global South, including the Middle East, have attracted an increasing amount of attention after the end of the Cold War and the bounds of enquiry have expanded to include a substantial 
number of neglected issues, a considerable gap still exits with respect to the foreign policies of the states of the global South in their post-colonial epoch (Çatı, 2013: 20-23). Syria in its immediate post-independence period is a typical example. This paper presents Syria as its subject of analysis and adopts a broader conception of foreign policy that does not leave issues of economic and social nature beyond the scope of enquiry.

How do socio-economic needs, resource endowment and political weaknesses of a country affect its foreign policy? How do characteristics of states affect the articulation of foreign policy goals and preferences? What were the main concerns of the leaders of the states that were burdened with varying degrees of underdevelopment, vulnerability, dependence and permeability at their independence? Taking these theoretical questions as a points of departure this paper aims to provide an overview of the development of Syria's foreign policy during the five-year period between the first coup d'état that took place in March 1949 and March 1954 coup that restored parliamentary regime in Syria. A domestic political economy approach in which socio-economic needs of the country are taken as a source of foreign policy and the acquisition of foreign economic resources as a major foreign policy objective is adopted in this study. Yet, this article does not suggest that a purely arithmetical cost-benefit analysis lies behind Syrian foreign policy moves. The contention is that socio-economic dimensions have been sufficiently important to warrant investigation.

\section{Theoretical Framework}

In a pionering work published in early 1970s, Franklin Weinstein called for studies that demonstrate 'how foreign policy relates to the political and economic problems that constitute the essence of being a less developed country' (Weinstein, 1972: 356). Accordingly, the importance of underdevelopment for the formation of foreign policy is not that it leaves a state at the mercy of stronger powers, but rather that it dictates some of the main concerns of the policy makers (ibid.: 365). The subsequent emergence of a body of literature that has been fittingly called 'the foreign policy of development' (Dessouki and Korany, 1991: 10) and the registering of 'acquiring foreign economic resources for development' as a distinct category under outputs (Wurfel \& Burton, 1990: 5; Spero \& Hart, 2003: 192) are a testimony to the firmness of Weinstein's line of inquiry which directs the researcher towards the application of a political economy approach in the study of foreign policy.

Despite the emergence of encouraging works especially in the 1990s (e.g., Wurfel and Burton, 1990; Levy and Barnett, 1992; Brand, 1995) political economy as an approach in foreign policy analysis remains comparatively underemployed (Korany, 1990: 32; Light, 1994: 101; Hudson, 2005: 13). This is more so in the case of Syria. Its rulers' quests for foreign economic resources to meet the needs of the Syrian economy have largely been neglected or undervalued in the analysis of the country's foreign policy in the immediate post-independence period. 
On the other hand, in power based literature of international politics and foreign policy the issue of resources has customarily been viewed as a problem of the arrangement of available resources and their allocation for the attainment of competing goals. More recently, the focus has been on the variation in the ability of states to extract and mobilise resources from their own societies.

For instance, Morgenthau elaborates on the dual problems of 'balance between resources and policy' and 'balance among resources' in his discussion of the quality of government as an element of 'national power' whose other components include geography, natural resources, industrial capacity, military preparedness, population, national character, national morale and the quality of government (Morgenthau, 1993: 124-163). Accordingly, good government, which is presented as an independent requirement of national power, has to 'balance between, on the one hand, the material and human resources that go into the making of national power and, on the other, the foreign policy to be pursued. ... Once a government has brought its foreign policy into balance with the power available to it, it must bring different elements of national power into balance with each other' (ibid.: 159). On this basis, the degree of compatibility of resources with policy ends is depicted as a measure of foreign policy performance (Morgenthau, 1993: 158-160; Hill, 1977: 1-17; Salmore \& Salmore, 1978: 103-122). In this manner policy makers are assigned the role of 'comparative analysts' 'since they have the perpetual task of relating diverse situations one to another and comparing what might be desirable with what is possible in the light of available resources' (Smith, 1989: 210).

In Fareed Zakaria's study that examines the transformation of American foreign policy from non-expansion to expansion in the late nineteenth century, resource extractive capacity of a state is considered as a main component of state strength which in turn is presented as an intervening variable between systemic imperatives and foreign policy. Contending that state structure and strength in relation to its society must be taken into account since they affect the amount of national resources that can be allocated for foreign policy purposes, Zakaria treats the variable of state strength as a continuum measured along four major dimensions: the degree of autonomy from society; the scope of governmental responsibilities; the degree of cohesion in central policy-making apparatus; and the ability to extract material resources. Thus, while strong states are defined as cohesive, autonomous, wealthy and maximal in scope, weak states are characterised as divided, society-penetrated, poor and minimal (Zakaria, 1998: 35-41). Gideon Rose, who coined the widely accepted term neoclassical Realism to specifically include Zakaria's study, aptly conveys the central empirical prediction of this strand of Realism: 'over the long term the relative amount of material power resources countries possess will shape the magnitude and ambition - the envelope, as it were - of their foreign policies: as their relative power rises states will seek more influence abroad, and as it falls their actions and ambitions will be scaled back accordingly' (Rose, 1998: 152).

In a more recent study Jeffrey Taliaferro presents a resource extraction model to explain variation in the types and intensity of internal balancing strategies that threatened 
states are likely to pursue. Treating states' external alignments as exogenous and delineating possible internal balancing strategies as 'emulation', 'innovation', or 'persistence in existing strategies', Taliaferro argues that state power, defined as the relative ability of the state to extract and mobilise resources from their societies, shapes the types of internal balancing strategies threatened states are likely to follow. As he explicates, his independent variable is the level of external threat or vulnerability, while variation in the level of state power is the intervening variable. In constructing his model Taliaferro holds the value of the independent variable constant in order to establish the role of state power as an intervening variable between systemic imperatives and the internal balancing strategies treated as the dependent variable. According to this resource extraction model of neoclassical Realism, states that have higher extraction and mobilisation capacity are better able to innovate or emulate the practices of the system's best performing states. On the other hand, states that stand at the opposite end of the spectrum in terms of extraction and mobilisation capacity are expected to experience greater difficulty in pursuing emulation or innovation and therefore are more likely to persist in their existing strategies (Taliaferro, 2009). Thus, all else being equal, states with high state power have a wider range of action and are in a better position to respond to what Kenneth Waltz had earlier called the systemic pressures of competition and socialisation (Waltz, 1979: 123-128).

In these power-based studies, the socio-economic resource endowment of a country or a state's capacity to extract societal resources appears as constraining or intervening variables. Neither is classified as an independent variable capable of explaining behaviour. Clearly, the capacity to extract societal resources for foreign policy purposes varies across different countries and over time. It also conditions the range of internal strategies and therefore has to be taken into account, as Taliaferro argues. Indeed, the range of internal balancing strategies is far more limited for a great majority of developing states which are not only highly constrained by societal forces but also lack the size and sophistication of the economy to effectively engage in emulation or innovation as adaptive strategies. As underscored by Michael Barnett in his study that focuses on the mobilisation of resources for national security in capitalist societies, 'many Third World leaders have professed a desire to achieve independent arms production and increase their autonomy, but their efforts have been frustrated by a lack of appropriate technology, an insufficient industrial base, and the ability to achieve the desired economies of scale' (Barnett, 1990: 539).

There is also little doubt that a country's resource base acts as a constraint on its foreign policy activity. For example, given the 'perennially anemic state of African economies, resource constraints, and the nagging challenges of development' (Babarinde, 1999: 216) it becomes hardly surprising to be informed that 'most African countries do not even maintain embassies in all the other states of their sub-region largely because of budgetary constraints' (ibid.: 216) or that Bostwana's thirteen embassies and missions abroad are some of the most 'skeletally staffed in the world, with some staffed with only two diplomats' (Zaffiro, 1999: 79-80). 
Yet, while the studies reviewed briefly above take the amount of national resources as given and focus on 'balance between resources and policy' and 'balance among resources' or 'the variation in the ability of states to extract and mobilise resources from their own societies for security and foreign policy purposes', this study takes the argument further: it presents a country's socio-economic needs, resource endowment and political weaknesses as a source of foreign policy. In other words, in line with the political economy approaches to developing countries' foreign policies, this study takes the socio-economic needs and political problems that constitute the essence of being a less developed country as an independent variable that shapes foreign policy goals and preferences. In this respect, this study follows the lead provided by Laurie Brand in her exemplary study that helped bridge the gap between the literature on political economy and security (1995:19):

Rather than seeking to understand solely how economic factors may constrain what foreign policies may be pursued, one may also legitimately ask: given a state's economic structure what sort of foreign policy behaviour may be expected? That is, to what degree are a leadership's or regime's estimates of its economic needs and weaknesses a source of foreign policy - the independent variable - rather than mere measures of capabilities to carry out foreign policy constructed on the basis or constrained by other factors?

Accordingly, in this study economic and social needs are presented as a source of Syria's foreign policy in the post-colonial era. An attempt will be made to demonstrate that Syria's low level of 'infrastructure' and its 'resource gap' make it plausible to identify the acquisition of external resources for economic development as a key foreign policy objective. The first of the key terms, infrastructure, is understood beyond its physical forms to include not only roads, harbours and railways, refineries and power plants, irrigation systems but also banking, education and health facilities deemed indispensable for a viable modern state, economy and society (Uphapp and Ilchman, 1972: 86). The second key term, resource gap, is defined as the idea of a shortfall between a countries's earning capacity and the amounts required to meet long-term investment needs and cover the balance of payments deficits (Waterbury, 1983: 36-37; Mayall, 1990: 118).

However, it is not suggested that a purely arithmetical cost-benefit analysis lied behind Syrian foreign policy moves. The contention is that economic dimensions have been sufficiently important to warrant investigation. The focus on the poorly endowed nature of the Syrian economy and the consequent quest for external resources should therefore be strictly seen as an artefact of the relative neglect of the resource-securing function of the foreign policies of the global South.

Moreover, although this article adopts the state as the unit of analysis and attempts an inside-out explanation that integrates the country's political processes and economic structure, the aim is not to substitute a domestic-centred determinism for systemic determinism. From the latter's point of view an inside-out explanation that brings into play the 'uses of foreign policy' may imply too much manipulative intent and capability (Hill, 
1977: 7; Smith, 1987: 346). In this respect, it is readily granted that the structure and the evolution of Syrian political economy are conditioned by the economic and geopolitical structures and processes of the international system. Yet, while imposing constraints, the international system also provides opportunities. It conditions development in the global South but does not preclude it. The variations in development performances within the global South as exhibited by the rise of newly industrialised countries of East Asia which appear to be on the way to bridging the economic gap between themselves and the advanced industrialised countries on the one hand, and the dramatic emergence of poverty-stricken states identified by the World Bank as the 'Heavily Indebted Poor Countries' (HIPCs) ${ }^{2}$ on the other, point to the necessity of taking sub-systemic factors seriously.

This view on development has been informed by 'the new comparative political economy' (NCPE) that emerged as a productive but 'messy' research programme in the 1980s (Evans and Stephens, 1988: 713-745). As conveyed in Peter Evans and John Stephens' authoritative appraisal, work falling in this tradition includes an assortment of studies on Latin America, Asia, Africa and Europe that share a number of vital characteristics despite their methodological eclecticism. While the study of development is basically understood as 'the study of long-term, large scale, socioeconomic and political change' (ibid.: 737), the NCPE rests on the key conviction that economic and political development cannot be fruitfully investigated in isolation from each other. Significantly, it is indebted to both Marx and Weber but underlines the incompatibility of 'straight jacket theoretical orthodoxy' inherent in the 'capital logic of Marx' and 'value determinist' readings of Weber. Moreover, NCPE has absorbed the lessons that grew out of work on dependency and world system perspective and is therefore sensitive to systemic constraints but rejects models that propose 'necessary' outcomes, maintaining instead that developmental paths are historically contingent (ibid.: 725). Finally, its recognition of historical and social-structurally rooted norms and values as well as its willingness to tolerate explanations that include political and ideational factors along with economic ones are sources of strength but leave NCPE vulnerable to contending elegant rivals that propose single-factor explanations.

\section{Historical Background: Syria at Independence}

At independence Syria had a population of approximately three million, dwelling in an area of about 185 thousand square kilometres (Etudes sur la Syrie économique (ESE), 1957: Annex 8). Its boundaries were artificial in the sense that they were more of an expression of the balancing interests of mandatory powers and those powers' policies and less of the reflection of the preferences of its people. Being an alien creation, whether it

2 HIPC refers to forty countries (mostly in Sub-Saharan Africa) with high levels of poverty and debt burden which are eligible for an ongoing debt relief initiative launched jointly by the International Monetary Fund and the World Bank in 1996. International Development Association and International Monetary Fund, 2011. 
commanded the prime loyalty of its inhabitants or not was as yet unresolved. Aspects of socio-political cohesion such as the identification of people with the state and its rulers (legitimacy) and of people with each other in a way that differentiated them from those left beyond the state boundaries (integration) were weak (Hudson, 1977; Seurat, 1980: 87-141; Mufti, 1996). Moreover, although the country benefited a wave of expansion during the Second World War due to the shortage of imports and the demands of the Allied troops in the region, its economy was underdeveloped, mainly agrarian and in need of diversification. Besides, the new state lacked basic infrastructure. Large sections of the country lacked adequate transportation and communication facilities, were without appropriate water and sanitary provisions and had no electricity. The inadequacy of roads, railways and power stations created bottlenecks. Immense problems were also posed by poverty and illiteracy (Makdisi, 1961; Sadowski, 1984: 115-202; Khoury, 1987: 624-626).

\subsection{The Regime of Husni al-Za'im, March-August 1949}

After months of political turmoil following Syria's poor performance in the 1948 war against Israel, the Syrian army led by its chief of staff General Husni al-Za'im elected government in a bloodless coup d'état on 30 March 1949. Although shortly after the coup Za'im announced his intention to restore civil government as soon as possible, it soon became clear that he was an ambitious politician with grandiose plans who wanted to stay in power and leave his mark on Syrian political life. Dismissing the parliament that refused to legitimise his rule, banning newspapers and abolishing all political parties to stifle his opponents, getting himself elected President in a railroaded and rigged referendum, taking up the alliterative title of The Leader $\left(a l-Z a^{\prime} i m\right)$ and investing himself with the rank of marshal, Za'im ruled Syria until August 14, when a group of army officers led by General Sami al-Hinnawi deposed and killed him (Ziadeh, 1957: 101-103).

\subsection{Attempts at Regime Consolidation}

The first Syrian military intervention attracted extensive support but this initial favourable reception emanated from the immense disaffection felt towards the old regime. The fate or longevity of the new regime, however, was to be judged by its own performance. In this respect although much has been written on Za'im's personal shortcomings and flaws in his character (Be'eri, 1970: 58; Seale, 1986: 61-63) both his determination to build up the Syrian army and his commitment to social reform, economic development and more prosperous society appear to be genuine. Thus, during his reign the size of the Syrian army was expanded nearly five-fold from 5,500 to 27,000 and it was re-equipped with arms purchased from France; Turkish assistance for its reorganisation was sought and a Turkish military mission led by a former Chief of the General Staff was received to accomplish this task; arrangements were also made to send junior military officers to Turkey and Egypt for training (Carleton, 1950: 5; Gazette de Lausanne, 1 July 1949; Arslan, 1994, 2: 810ff). Following the example set by Mustafa Kemal Atatürk, the founder of modern Turkey, Za'im endeavoured to separate religion and state. Syria under his rule became the first Arab country 
to grant the franchise to women; ${ }^{3}$ the scope of the Muslim shari' $a$ law was restricted by the substitution of a civil code drawn up in Egypt on the European models by a group of jurists eager for legal reform; and the private administration of family waqfs ${ }^{4}$ was abolished to pave the way for agrarian reform. Moreover, a Directorate of Statistics was established and the Syrian (later Damascus) University, which had been established in 1923 by the addition of a college of Letters and Sciences to the Ottoman Schools of Law and Medicine, was reorganised on more Western lines. A commercial law was issued and the principle of progressive taxation was adopted with the declared aim of equitable taxation but undoubtedly increasing the revenues of the state was another motive (Kayali, 1951: 275, note 3; Seale, 1986: 58-63; Fansa, 1982: 182-183). These reforms and measures were highly significant and most of them survived their initiator. However, more radical action was needed to fulfil Za'im's ambitions.

Back in 1946, a British firm, Sir Alexander Gibb \& Partners, had been contracted to study the country's economic resources and development potential. The report submitted to the Syrian government a year later included a list of the feasible projects, underlined the necessity of additional detailed technical studies for some of these projects and recommended the immediate undertaking of the rest. At a time when government revenues totalled about SL125 million (Syrian Statistical Abstract (SSA), 1950: 118-119), the British firm proposed a ten-year SL477 million public works draft plan ('Ammari, 1964: 33). However, due to the lack of funds, the plan had not been adopted and instead the civilian governments formed prior to Za'im's coup ${ }^{5}$ had proceeded to tackle some small-scale projects such as the Khabur River Irrigation ${ }^{6}$ or Madkh Swamp. ${ }^{7}$ Yet the Gibb plan, although practically shelved, became a blueprint for the country's economic development (Petran, 1972: 88).

Upon seizing power $\mathrm{Za}$ 'im announced the immediate undertaking of some of the projects covered by the plan, such as the Latakia Harbour (SL28 million) and the Euphrates Water Project for Aleppo (SL28 million) (Carleton, 1950: 6; Seale, 1986: 58-63). At the same time Za'im promised that the economy would not depend on taxes which strain industry and employers (Van Dusen, 1971: 208). Recognising the scarcity of domestic

3 Initially, this right depended on literacy, but within one year this restriction was also removed.

4 Al-Awqaf al-dhuriya, religious endowments whose revenues are allocated to the descendents of their founders.

5 In the post-independence three-year period leading to Za'im 's coup, governments had been led by the following prime ministers: Sa'dallah al-Jabiri and Jamil Mardam, both from the National Party, and Khalid al-'Azm, an independent (Jabbur, 1993: 58).

6 Irrigation of an area up to 34,000 hectares (1 hectare $=10,000 \mathrm{~m}^{2}$ ) with the waters of the Khabur River, an east bank tributary of the Euphrates.

7 A project for drawing off water from the Queiq River -north of Aleppo-to irrigate some 15,000 hectares and the limitation of the swamp area flooded by the waters of the same river. 
resources $\mathrm{Za}^{\prime}$ im tried to exploit external challenges and opportunities to acquire funds sufficient to implement the whole plan.

In the following few months a series of agreements with either the 'one foreign power to which one could not show partiality without weakening the nationalistic fervor of a quarter century of struggle against the Mandatory Power' or with the oil companies of 'the concession-hunting imperialists' (Carleton, 1950: 7-8) or with the 'Zionist enemy' (Shlaim, 1986: 72) were proposed or signed or ratified. As we shall see, apart from getting international backing for his regime, either the acquisition of external financial resources to foster economic development or opening the way for the free exercise of legislation in financial matters for the same purpose was a central concern common to these agreements.

By not shying away from the ratification of the pipeline agreements that provided for the conveying of crude oil from Saudi and Iraqi oilfields to the Mediterranean, Za'im manifested a certain willingness to come to terms with the interests of Western oil cartels that were backed by their respective governments and the neighbouring Arab states that endeavoured to increase their oil revenues. Underlining the country's strategic location in the oil-rich Middle East, these very agreements were also instrumental in embedding Syria to the rent circuit as a transit state.

The rapprochement ensuing the ratification of the monetary agreement with France, the former mandatory power, opened the way for the purchase of French weaponry for the Syrian army which was undergoing a major expansion while assistance for its reorganisation was received from Turkey whose leaders were all too happy to see a regime that was inclined to cast aside the problematic issue of Alexandretta (Hatay).

In his bid to procure the funds needed to bolster his shaky regime, Za' im formulated or adopted proposals that were in harmony with the Western and particularly US sponsored plans that aimed at the peaceful resolution of the Arab-Israeli conflict. In a similar vein, he was prepared to accept Western perceptions of threat and go as far as offering to provide military air bases to be used to 'contain' the Soviet Union. The peace offer to Israel and willingness to resettle 300,000 Palestinian refugees in Syria is best understood in this context (Shlaim, 1986; Pappé, 1992; Rabinovich, 1991; Ma'oz, 1995). Za'im contemplated that helping to solve the thorniest refugee problem and contributing to the comprehensive settlement of the Arab-Israeli conflict would not only remove the destabilising question of Israel from Syrian politics but would also provide the funds and technical assistance for building infrastructure, extending the area under cultivation, modernising the agriculture and raising the living standards throughout Syria. His willingness to take a leading role in the creation of a some sort of Middle East defence system based on alliance with the Western powers in return for economic and military aid or his plan to ask for a loan of $\$ 100$ million from the US to be strictly used for his economic and social program, when his peace and resettlement offers failed largely due to Israel's uncompromising attitude towards repatriation of refugees and its preoccupation with the territorial issue, further prove that a main concern in Za'im's foreign policy making was attracting external resources for 
economic development of Syria and building up its army. He was, it seems, ready to breach the norms of Arabism against a separate peace with Israel or entering some sort of military alliance with the Western powers if the returns were worth such undertakings.

\section{Hinnawi’s Interlude, August 1949-December 1949}

The leader of the August military coup General Hinnawi installed himself as chief of the armed forces and assumed the chairmanship of the eleven-man 'Supreme War Council' (al-Majlis al-harbi al-a'la) whose formation was announced on the day of the coup. In their first communiqué these officers claimed to have acted to put an end to Za'im's tyrannical rule and promised to leave the administration of the country to its civilian leaders (Mu'allim, 1985: 117-119; Hawrani, 2000, 2: 1006-1007). Within a couple of days and after a series of meetings between the leaders of the coup and a group of civilian politicians and among the latter themselves, legislative and executive powers were handed over to a provisional cabinet formed under venerable Hashim al-Atasi. ${ }^{8}$

Upon assuming power, the Atasi government held the elections for a Constituent Assembly in mid-November, with eighteen-year-olds and women voting for the first time in the history of any Arab country. The returns gave the People's Party dominance in the Constituent Assembly which was known to be favourably disposed towards some sort of unity with Iraq.

The pro-unity stance of the People's Party towards Iraq emanated from the political rivalry between Aleppo and Damascus and had economic considerations as underlying factors. Aleppo had prospered within the unity of the Ottoman Empire and suffered more than Damascus from the arbitrary post-World War I partitions. The loss of the greater part of its commercial hinterland had forced a drastic contraction of its economy during the inter-war period (Khoury, 1987: 623.). However, during World War II, the difficulties of obtaining manufactured goods from traditional foreign suppliers together with the increased demand for consumption goods brought about by Allied expenditure stimulated local industrial growth and in turn led to major investments by Aleppine entrepreneurs in the Jazira region expanding the margins of cultivation. The area under cultivation, including fallow land, rose from about 1.76 million hectares in 1938 to 2.3 million in 1945 and reached 3.09 million hectares by 1950 (International Bank for Reconstruction and Development (IBRD), 1955: 18-19). As Yusif Sayigh (1978: 238) maintained their contribution went beyond 'opening up of the north-eastern frontier' and included the introduction on a large scale of machines, building of roads, installation of irrigation pumps and creation of irrigation networks, the financing or arranging finance

8 For the list of the main participants, the details of the meetings, the composition of Atasi government and the text of its policy statement, see Mu'allim, 1985, Document No. 15: 331-334. 
needs and finally introducing new tenure arrangements. The resulting economic boom enabled Aleppo to re-emerge as Syria's main entrepreneurial centre in need of expanding its northern and eastern commercial hinterland. As Philip Khoury (1987: 623) argued, while Turkey remained hostile to this idea, Iraq was encouraging. The political expression of Aleppo's economic interests was embodied in People's Party and hence came its commitment to the removal of trade barriers and the abolition of Syrian-Iraqi frontier within which, in Patrick Seale's (1986: 30) words, 'Syria suffocated'.

The opposition to union with monarchical Iraq, which later styled itself the Republican Bloc, was led Mustafa Siba'i of the Muslim Brotherhood and Hawrani of the Youth Party. The adherents of the Republican Bloc were unwilling to sacrifice Syria's republican regime for a monarchy. Moreover, pointing to the Anglo-Iraqi Treaty of 1930 that sanctioned British influence in Iraq, ${ }^{9}$ they claimed that a union with the latter would inevitably bring Syria too under the 'yoke of imperialism' (Hawrani, 2000, 2: 1026-1114). The showdown came over the wording of the oath to be taken by the Head of State and the members of the constituent assembly. The approval of the text of the oath that made no mention of Syria's republican regime, signified a clear victory for the supporters of the union with Iraq (Hawrani, 2000, 2: 1107).

However, for the opponents of the union, especially for some influential officers in the Syrian army too much was at stake. As Patrick Seale asserted, they were republicans, they could not tolerate being under British tutelage and they did not want to take a secondary position in the larger Iraqi army (Seale, 1986: 81). On the night before the swearing-in of the Head of State, which was scheduled for 19 December, the third coup d'état was carried out by the Commander of the First Brigade Colonel Adib al-Shishakli.

\subsection{The Rule of Shishakli}

The first communiqué issued by Colonel Shishakli on 19 December 1949 stated that the army had been compelled to put an end to the conspiracies of the Chief of General Staff and some 'contemptible politicians' who, together with some foreign circles, threatened the 'integrity of the army, the survival of the state and its republican regime.' Moreover, the communiqué included a pledge to leave the affairs of the country in the hands of its legally elected representatives and not to intervene in the political affairs 'unless the security and survival of the country renders it necessary'. ${ }^{10}$

\footnotetext{
9 For the provisions of the agreement which reduced Iraq, in the words of an author of a monumental work on the country, into 'an appendage of the British Empire' (Batatu, 1978: 545).

10 Communiqué No.1 dated 19 December 1949 as reproduced in 'Azm, 1973, 2: 226-227.
} 
Despite this concluding remark, Shishakli proved himself no less ambitious than the leader of Syria's first coup, Za'im. Although Atasi was initially retained as Head of State and the Constituent Assembly was allowed to function, Shishakli led another coup d'état that put an end to the pretence of a parliamentary regime on 29 November 1951. Yet while $\mathrm{Za}$ 'im had climbed to the presidency of the state within the third month of his rule, Shishakli proceeded to pull the strings as a strong man behind various governments that followed his coups until he finally got himself elected President in July 1953 (Mu'allim, 1985: 136-160).

On his way to the apex of the administrative hierarchy, Shishakli resumed what had been initiated under Za'im: social and economic reform by decree. In this respect, the six-month period from his second coup until the summer of 1952 was most notable as it witnessed the issuing of over 250 degrees most of which dealt with educational, social and economic problems. As Walid al-Mu'allim (ibid.: 158) maintains, Shishakli attempted to show his critics that what could not have been achieved during the previous six years could be accomplished within only six months. These and subsequent measures, for example, extended government control to foreign as well as to Syrian private schools and forbade the opening of new missionary schools; made the approval by the Ministry of Education a requirement for the receipt of funds from abroad for educational purposes; attempted to raise the standards in secondary schools by the compulsory teaching of English and French; stipulated the reorganisation of scouting and sporting associations to eliminate all suggestion of an exclusive ethnic membership; terminated the last vestiges of communal representation established by the French and diluted by the governments of the post-independence period; abolished Druze and Alawi personal laws and brought the members of these communities under Syrian law; ordered the religious leaders and mosque functionaries to wear a standard costume; promised state backing for vocational training, the teaching of illiterates, the building of social centres, subsidised pharmacies and low-cost housing; empowered the Ministry of National Economy to issue decisions concerning the fixing of working hours and weekly holidays, illicit competition and the allocation of funds for social assistance in trade unions; required merchants to keep records in order to collect income taxes more effectively, increased inheritance taxes as well as taxes on high incomes and reduced some indirect taxes but these did little to dent the regressive nature of the prevailing tax system (Allouni, 1959: 68-69 ; Seale, 1986: 121; Seurat, 1980: 116).

It is noteworthy that when Shishakli assumed power Syria still lacked a central bank of its own because France, as the mandate power, had granted the exclusive right to issue a new paper currency, the Syrian-Lebanese pound, to a private French bank later renamed Banque de Syrie et du Liban (BSL) The decisive step towards establishing a central bank and a centralised monetary system was taken with the introduction of a basic monetary law in March 1953 (Asfour, 1959: 55-60; 'Arafat \& Malik 1996: 340-343). Besides aiming at the regulation of banking activity and reorganisation of the currency system, the law laid the basis for the establishment of the Central Bank of Syria (CBS) and the formation of a central monetary authority called the Currency and Credit Council (Majlis al-naqd wa altaslif) (CCC). The formation of the CBS, however, awaited the conclusion of the negotiations with the BSL for the cancellation of its concession which was to last until 1964 
if the convention signed during the mandate period was allowed to run its full course. Agreement which provided for the payment of an indemnification of SL300,000 for each year of the remaining period of the concession was finally signed in September 1955 and the CBS was officially inaugurated in August 1956 (MEE, October 1955:170 and August 1956: 122).

While government action concerning monetary policy concentrated on institution building and provision of a legal framework, Syria still lacked a fully developed financial infrastructure that would mobilise available resources to meet the investment needs of the economy. As an example, it is notable that in a country that aspired to capitalist development, interest rates were not regarded as a policy tool to influence the direction of the economy. Instead, a general legal maximum of 9 percent per annum was kept as the only provision concerning interest rates throughout the period (Asfour, 1959: 63).

Another key measure taken by the Syrian government during the 1950-53 period was the unilateral abrogation of the customs union with Lebanon in March 1950. ${ }^{11}$ The Syrian-Lebanese customs union was a legacy of the mandate period but the divergence of the economies of the parties had made it increasingly difficult to agree on a common policy on the question of tariffs. While the Lebanese government had felt no obligation to alter the tariff structure since its economy was based on services and entrepôt trade, the Syrian government had favoured modifications to protect its agricultural and industrial production. The Syrian position reflected the view of the local bourgeoisie whose representatives organised a conference in Damascus in early March and produced a report which served as the basis of government policy. Immediately after the abrogation the Syrian tariff on imports of certain products which competed with local industry was increased from 25 percent $a d$ valorem to 40 percent or 50 percent (IBRD, 1955: 378-379).

Afterwards, government regulation and protectionist policies became more pervasive. In March 1952, the business and investment freedom of non-Syrians, particularly the Lebanese middlemen and investors, was restricted by a decree forbidding foreign companies to carry out business in Syria unless they had Syrian representatives (Barakat, 1954: 6).

Moreover, the Ministry of Finance had been sponsored a programme of lowinterest loans to Syrian industrial corporations for their establishment or to enable them to continue operations. Reflecting the commitment to the fostering of the nascent Syrian industry the interests rates applied to the loans were kept below those prevailing on the capital market and the beneficiaries could secure an extension by the time of repayment (IBRD, 1955: 381-382). Underscoring this favourable attitude towards Syrian entrepreneurs

11 For the text of the decree (Legislative Decree No. 71 of 14 March 1950) and a detailed account of the SyrianLebanese negotiations preceding the abrogation of the customs union, see 'Azm, 1973, 2: 5-78. 
which marked Shishakli's rule, George Jabbur (1993: 60) has fittingly described the period as 'the golden age of Syrian bourgeoisie'.

State support to the Syrian agriculture in the form of bank credit was given a new impetus especially after the cotton fungus epidemic in 1951. The Agricultural Bank of Syria, a government institution that was the local successor to the nineteenth century Ottoman Agricultural Bank, was reformed and its capital was expanded to alleviate the losses of the affected landholders and to meet seasonal credit needs (Barakat, 1954: 6). As Sadowski (1984: 220-221) maintains, notwithstanding the broadening of the range of the borrowers, most of the beneficiaries still were owners of large or medium-sized landholdings who not only survived the cotton crises but even expanded their plots at the expense of smallholders who could not escape bankruptcy.

Concomitant with the expanding role of the state in the economy Syria began to acquire quite a sizeable public sector. In the 1950-1954 period the flourishing of the public sector took place in two main ways: On the one hand, state agencies were formed to assume responsibility for the implementation of needed development projects. On the other hand, foreign owned concessionary companies were taken over by the state. Of these, some such as water and electricity utilities, railways as well as the Régie de Tabac, the French-owned tobacco monopoly, were nationalised against indemnification (ibid: 186-187). Some others were taken over by the state at the expiration of their concessions as was the case with the French Lighthouse Company (MEE, December 1953: 11).

Shishakli's attempt to solicit support and alleviate rural poverty through the distribution of state lands to landless peasants that amounted to almost 60 percent of the agrarian population (Hinnebusch, 1989: 29-30) also foundered without producing any tangible result since, given the lack of an adequate cadastral survey, the state could not ascertain both the area and the location of the unregistered state domain (Dabbagh, 1962: 4). Although a new cadastre was started, Shishakli was overthrown before the actual redistribution of any lands (Sadowski, 1984: 215).

\subsection{Development Planning and Public Investment in Development Projects}

It has been rightly observed that successive governments did not have a comprehensive economic development plan during the first decade following independence. As a Syrian expert stated (Barakat, 1954: 15):

Development projects were studied and approved piece-meal under pressure of need and circumstances, without reference to any general programme, and without being subjected in their administration, execution, or the management of their financial and economic effects, to one single authority that could direct the whole operation and create the conditions for its success. The projects had nothing in common except the great need felt for them and the necessity of funding the required funds. 
In the absence of a complete list of the needed projects put in an order of priority, an estimate of their cost and the time required for their execution as well as lack of sufficient capital, Syrian rulers were bound to have an uphill struggle in their endeavour to improve and increase production and raise living standards. However, a process was put in place that would eventually lead to achieving this vital aim of formulating a long-term development plan and a single authority to manage it. The preparation of a general development plan by the Syrian Government was reported in 1951 (MEE, June 1951: 10).

In February 1953, it was reported that the Syrian Government was studying the use of foreign capital to finance its development and financial schemes that were estimated to cost about US\$ 500 million, almost eight times more than government revenues in the 1953 budget or an amount slightly larger than the Syria's national income in 1953. As part of the same study, discussions with the representatives of the IBRD took place and the Syrian envoys abroad were instructed by the Government to publicise the development projects of the country in international financial quarters. The following month, the Syrian Government decided to adopt a five-year large-scale construction programme that would entail the evaluation of a multitude of projects and their harmonisation and classification under the point of view of increasing national production (MEE, February 1953: 11) Therefore, by the end of 1953 Syria had reached the point where the need for a long-term development programme gained sufficient ground to prompt the President Shishakli to commit the state's development policy to the idea (quoted in Barakat, 1954: 17):

The state's future development policy must be embodied in an economic development programme that includes all the projects of the government and public institutions. We consider that this programme should cover a period of not less than five years... It is necessary that the programme should have a special administration directly linked to the Office of the Chief of the State... The Administration should undertake the study of projects and estimate their importance, order of priority, probable benefits, the length of time needed to carry them out, and their cost. It should prepare technical specifications and after approving them should supervise their execution.

Meanwhile, despite being piece-meal and not part of a general plan, public investment in Syria's infrastructure had already started to gain some momentum after 1950. Apart from public utility projects such as automatic telephones, electricity installations and Aleppo water scheme, and in addition to road construction and small-scale irrigation projects, ambitious projects such as the reclamation of Ghab and the Latakia Port were initiated (Asfour, 1959: 80.) Development projects were financed from four sources. First, from appropriations allocated from the state budget; secondly, from available treasury funds; thirdly, from the loans advanced by the Issue Department of the BSL; and finally from foreign loans such as the $\$ 6$ million interest-free Saudi loan (Barakat, 1954: 10). 


\subsection{The Search for Financial Aid}

During the period that followed independence the Syrian economy grew at a fairly remarkable pace, exports increased at an impressive rate and a greater proportion of the national income was extracted and spent by the state. However, despite all these developments, Syria was still experiencing a negative balance of trade and substantial budget deficits while the regressive nature of the tax system and the unequal distribution of the benefits of growth were causing resentment and instability (Çatı, 2013: 122-125).

Against this background, there was almost a consensus that a shortage of capital was the principle factor limiting further economic development and that massive public investment, particularly in irrigation and power schemes and transport facilities, would be needed to achieve breakthroughs. The dilemma faced by Syria's rulers was aptly described by the Secretary of the Currency and Credit Council of Syria (Barakat, 1954: 7-8):

The Syrian economy needs capital and finance projects that will create conditions favourable to its growth; but, as a result of its weakness and underdevelopment, it lacks the necessary financial means. In other words, the state's financial capacity is small and cannot expand unless national production grows; and national production cannot grow unless the state's financial capacity expands. How then, are we to get out of this vicious circle?

As Za'im had tried earlier, the powerful man behind the third and fourth military coups in Syrian politics, Adib al-Shishakli, turned abroad in an attempt to secure the funds needed for development projects. Only three weeks after his first coup d'état and a day after the vote of confidence that took place on 7 January 1950 for 'Azm's compromise cabinet, Shishakli embarked on a trip to Egypt and Saudi Arabia to demonstrate that he was in control of Syrian politics, repair the breach caused by the Hinnawi interlude and explore the possibilities of obtaining financial assistance from these two Arab states which preferred an independent Syria rather than one united with the Hashemite Iraq. The assertion that financial assistance was subject of discussion between the parties and that it was sought to provide funds for the much-needed economic development projects was subsequently confirmed before the end of the same month. On 24 January it was announced that the Saudi Arabian Government had agreed to extend a \$6 million interest-free loan to Syria. This amount represented nearly one-sixth of the ordinary budget of the central government in 1950. According to the announcement that was made during the follow up visit by the Syrian Minister of National Economy, Ma'ruf al-Dawalibi, Syria was to receive the agreed amount in three instalments over a seven-month period and repay it in goods in four annual equal instalments in 1955-1958. According to Patrick Seale, this loan together with a $£ 5$ million promised but never paid loan by Egypt during Shishakli's visits to Cairo and Riyad, was the price for underwriting the Syrian independence from the Hashemites (Seale, 1986: 92). In effect, the conclusion of the loan agreement in January 1950 signified the active recognition by the Syrian Government of the validity of the Tapline agreement which had been left at abeyance following the death of $\mathrm{Za}^{\prime} \mathrm{im}$. Thus it was not a coincidence that Aramco was 
approached by the Saudi government for an advance to finance the loan and that the first instalment was paid by the Saudi authorities to their Syrian counterparts after the oil giant's compliance with their request. As a result of this loan, the Syrian Government issued a decree announcing the beginning of works at the port of Latakia on 13 February (Ziadeh, 1957: 109). Only five days later, the New York Times reported that the Syrian government had undertaken 'to use eminent domain to obtain the necessary stripe of land' needed for the pipeline (New York Times, 18 February 1950). The balance of $\$ 4$ million, on the other hand, was handed over by the end of 1950 as work progressed in both the Latakia port and Tapline projects (Holden \& Johns, 1981: 149).

Another opportunity for the Syrian regime to attract technical assistance and economic aid for its development projects became available when President Truman proclaimed 'a bold new programme for making the benefits of our scientific advances and industrial progress available for the improvement and growth of underdeveloped areas' in his inaugural address in 1949. The programme, which widely became known as Point Four, received final legislative and executive approval in early 1950 and allocated $\$ 10$ million to Syria (Hakim, 1950; Gardiner, 1950). Although this sum represented approximately one half of the total Point Four aid to the Arab countries, it was rejected by the Syrian Prime Minister at a special press conference in June 1951 (MEE, June 1951: 10). Despite leaving the US officials in Syria perplexed and frustrated (Lesch, 1990: 41) a close examination of the conditions and the size of the aid against the expectations of the Syrian leaders may uncover the underlying reasons behind the decision for its rejection. First of all, the nature of the criteria to be applied to the requests of assistance raised questions of foreign influence and control by giving the authorities implementing the programme in the United States almost a veto power over the development projects of the recipient countries. Besides, there was also a strong suspicion in Damascus that technical experts sent from the United States within the framework of the programme would meddle in Syria's political affairs (MEE, June 1951: 10). Moreover, a fundamental premise of the Point Four aid was that United States private capital would flow to the underdeveloped countries for the realisation of a wide range of a projects to be recommended by the technical experts of the programme but the widely held belief in the Middle East was that private American capital would not cease to confine its main investments to the exploitation of the region's oil resources (Hakim, 1950: 189-193). Therefore, while the Point Four aid allocated to recipient countries was intended to pay for educational and training programmes, preliminary surveys and feasibility studies, it made no direct provision of capital grants for the implementations of the projects which the Syrian themselves wanted. Finally, Truman's programme required contribution towards the cost of the Point Four technical assistance projects from the local treasuries concerned. As Shishakli himself explained (quoted in Ziadeh, 1957: 136):

I have already stated that we are a small nation with limited financial resources and that we have a large-scale constructional programme involving many vital projects, for the execution of which we are in real need of great deal of assistance. We consider Point Four assistance, however, unsuitable and insufficient, in as much as it is meant to help backward nations in making 
studies of possible projects rather than in the execution of projects already studied and prepared. In fact we are fully aware how important it is that careful study should precede execution, but we do have many vital and urgent projects awaiting execution that we feel that the contributions we shall be required to make to the operation of the Point Four Assistance Programme can be more profitably and usefully used elsewhere. This is the reason why we have rejected Point Four assistance.

Although the conditions of the Point Four assistance were unacceptable and its size was considered to be insufficient, this rejection did not mean that Shishakli's regime completely gave up its search for US aid, it was actually holding out for a better deal (MEE, June 1951: 10). Subsequently, the most important and radical move in search of financial aid and technical assistance for the accomplishment of economic development and social reforms came out in the form of a peace offer made by Shishakli to Israel after his establishment of direct military rule in late 1951.

Shishakli was a pragmatic ruler who had participated in the 1948 war as a deputy commander of the Arab Liberation Army. He had experienced the defeat of his forces in Upper Galilee and was aware of the military might of the Israeli Army. Following his seizure of power he engaged in a systematic effort to strengthen the Syrian army but periodic violent confrontations precipitated by inexorable Israeli unilateral actions to extend its control in the demilitarised zone served as reminders of unbroken Israeli military superiority (Khouri, 1963: 19-23). Rather than fighting the Israeli state and facing an eventual defeat in a general war, Shishakli sought a political solution that could bring benefits to Syria and put the IsraeliPalestinian issue off the Syrian political agenda. Even before the peace offer, in February 1951, he had initiated a compromise proposal regarding the DMZ and later, in March, he had personally taken part in direct negotiations with the Israeli deputy chief of staff, Mordechai Makleff (Ma'oz, 1995: 29). Moreover, as he emphasised in his meeting with the U.S. Secretary of State, John Foster Dulles, during the latter's visit to the Syrian capital in May 1953, he was not one of those Arabs who denied Israel's right to exist nor he was committed to pushing it into the sea. Instead, he expressed the more moderate demand that Israel adhere to the UN resolutions relating to the refugee problem, border demarcation and the internationalisation of Jerusalem. During the conversation, he also claimed that Syria had to spend half of its budget on defence and pointed out that the US had the capability through economic and military assistance to keep Syria independent (Lesch, 1990: 64-65: Little, 1990: 61). As Moshe Ma'oz put it (1995: 30):

Even though, unlike Za'im, he was an Arab nationalist, Shishakli, like Za'im and several other Syrian leaders, adopted a pro-Western, notably a proAmerican orientation aimed at obtaining both American military equipment and economic assistance. Shishakli continued his search for financial aid, to carry out his ambitious socio-economic reforms, and for modern weapons, to safeguard his rule against a possible Israeli attack. In return for the required American help, Shishakli was prepared, like Za'im previously, to enter a 
Western alliance vis-à-vis the Soviet Union and also make peace with Israel in accordance with the American demand.

The peace offer was unmistakably similar to Za'im's proposal in the sense that it stipulated a political agreement with Israel by way of the United States in return for economic and military assistance. At this point it should be made clear that the offer made by Shishakli to Israel fell short of a peace agreement as it did not include commercial and diplomatic relations. It rather resembled a non-belligerency agreement that would bring to an end the armed clashes along the border, particularly in the demilitarised zones, and pave the way for a full peace treaty after public hostility to such an idea could be overcome. As conveyed by Shishakli and his defence and subsequently prime minister, Fawzi Selu, to American, British and French diplomats as well as UNRWA officials, within the nonbelligerency agreement, Syria would be ready to absorb about half a million Palestinian refugees from Jordan, the Gaza Strip and Lebanon in addition to the 80,000 refugees already in Syria on the condition that Syria would be given \$200 million for economic development. The available resources reveal that the United States welcomed the proposal and was willing to deliver some weapons as well as economic assistance (Ma'oz, 1995, p. 30; Landis, 2001: 77-87). Nevertheless, Shishakli's regime did not sign either any economic or military agreement with the United States or a non-belligerency agreement with Israel.

Then, if Shishakli was so keen on acquiring financial aid and technical assistance for the implementation of Syria's badly needed economic development projects, why did not he grab such a significant opportunity? This question is basically related to the broader issue of state-society relations in Syria at that time. There is no doubt that Shishakli dominated Syria's political scene from his first coup in December 1949 until his deposition in February 1954. Despite the pretension of an existence of a civilian regime after his first coup and the attempted transition to a civilian regime after his second coup, Shishakli reigned supreme throughout his long tenure. However, this supremacy was not automatically translated into complete autonomy from society or other political actors. The regime could not afford to ignore widespread domestic opposition to Western aid which was tied to the settlement of the Palestinian refugees in Arab countries despite United Nations resolutions calling for their return to Palestine. Any such deal was commonly equated with capitulation to Western imperialism and submission to Israel. Adherents to this view included politicians from across the political spectrum. For example, Ma'ruf al-Dawalibi, a leader of the People's Party who served as the minister of national economy in early 1950, resented American attempts to bring about Arab-Israeli peace at the expense of Palestinian refugees. He declared that such an agreement would lead to the 'Judaisation of the rest of the sons of the Arab people' and that 'the Arabs would a thousand times prefer to become a Soviet republic rather than become prey to the Jews'. ${ }^{12}$ Likewise, Muslim Brotherhood leader Siba'i 
proposed that Arabs turn towards the Soviet Union for diplomatic support to counter AngloAmerican pressures (Petran, 1972: 101). Moreover, a movement against joining a western defence pact and arguing for Syria's neutrality in the Cold War was being led by Hawrani and the $\mathrm{Ba}^{\prime}$ th Party and was gathering pace in attracting widespread support from the public, civil politicians as well as some military circles. The anti-Western sentiment gained so much momentum that after the outbreak of the Korean War, Syrian newspapers rejoiced in US defeats and the Anglo-American military and political delegations visiting Syria were greeted by extensive protest demonstrations (Kayali, 1951: 244). The spread of the rumours of talks with American and French diplomats caused upheavals even within the army, the power base of Shishakli's regime and prompted a swift reaction. On 24 December 1952, the General Staff issued a communiqué announcing the uncovering of a plot against the regime and the arrest of a number of officers who 'had allowed themselves to be trapped by subversive ideas spread by certain extremist politicians' and that 'the accused had been spreading tendentious reports to the effect that the Government was about to join a western Middle East defence scheme and had agreed to settle Palestinian refugees in Syria'. Shortly after, Hawrani and the two Ba'th leaders, 'Aflaq and Bitar, secretly crossed the Lebanese border to avoid arrest and reiterated their allegations to the Beirut press (Abu Jaber, 1966: 32). ${ }^{13}$ Facing dissension in the army, disaffection among politicians who had been his closest civilian supporters, intense public opposition as well as an uncompromising Israeli leadership, Shishakli was consequently forced to shelve the peace proposal. Finally, the Qibya massacre ${ }^{14}$ committed by Israeli Army dealt the deadly blow to the prospects of an immediate Syrian-Israeli deal. As Barnett (1998) highlights such an undertaking would run counter to the norm of Arabism that prohibited relations with Israel or dealing with the West in a way that could run against the general consensus.

Despite this major setback, the Syrian regime continued to seek foreign aid whenever possible even when it involved the very contentious issue of the resettlement of Palestinian refugees. Thus, in October 1952, an agreement was signed between the Syrian government and UNRWA for providing homes and livelihood for 73,000 Palestinians who had taken refuge in Syria, thereby removing them from the care of the UN agency. The project involved an eventual investment of $\$ 30$ million to be supplied by UNRWA and included a land reclamation programme. The land was to be provided by the Syrian

13 While in Lebanon in exile, these three leaders decided to join forces and effected the merger of their parties. The new political organisation was henceforth called the 'Arab Socialist Ba'th Party' (Hizb al-ba'th al-'arabi al-ishtiraki).

14 The incident took place in October 1953, when Israeli troops dressed as 'irregulars' attacked the Jordan-held West Bank village of Qibya, killing around 42 men, women and children and injuring 15 other. This attack, led by then Major Ariel Sharon, came in retaliation for the murder of an Israeli woman and two children. The outcry inside Syria was intense, prompting the Syrian regime to put its army on alert and send two-third of its strength to the Israeli front. The killings caused such dismay that the USA, Britain and France led the condemnation of Israel within the Security Council and agreed to express their 'strong censure'. See Lesch, 1990: 76; Khouri, 1966: 438; $\mathrm{Ma}^{\prime} \mathrm{oz}, 1995: 47$. 
government from state domains part of which were desert areas that could be cultivated if water were available. As a sign of awareness of the delicacy of the issue, both parties refrained from calling the project 'resettlement' but referred to it as a project of 'rehabilitation' or a 'project for the ameliorating the condition of refugees and making them self-supporting' (MEE, November 1952: 12).

UNRWA succeeded in concluding similar agreements with some other Arab states including Egypt and Jordan but failed to realise its 'refugee rehabilitation programme' by June 1954, the deadline set for it by the UN General Assembly. As the director of the agency stated in his report, UNRWA had received no cash in the year preceding the dateline for its 'rehabilitation' projects and that pledges by the United States and the United Kingdom, the two major donors, to UNRWA for that purpose had remained unpaid. Meanwhile, the Agency had used its accumulated funds to sponsor two small projects on marginal lands at Ramadan and Dabaa in Syria but the results were disappointing and the costs higher than expected due to the nature of soil and the lack of water. Moreover, 466 refugee families benefited from 'small self-support grants' (United Nations, 1954: 76-77). A development which took place during the year [July 1953-June 1954] covered by the Agency's report but not mentioned in it is in order here: Shishakli was driven from his country by a military insurrection in February 1954. Neither the Syrians nor the Western states were to seriously raise the issue of resettlement of refugees in Syria again.

\section{Conclusion}

This paper has aspired to enhance our understanding of the relationship between economic development and foreign policy in Syria in the post-independence period. In this endeavour, Syria has been taken as a state of the global South that came to independent statehood burdened with varying degrees of underdevelopment, dependence, vulnerability and permeability. Foreign policy in a country like Syria was bound to be engrossed with the uneasy task of overcoming these debilitating conditions or making them manageable. Thus socioeconomic needs of the country have been presented as a source of foreign policy and the acquisition of external resources has been identified as a key foreign policy objective.

Although marked by a series of military coups and a multitude of short-lived governments, the period from the deposition of the elected government until the reestablishment of parliamentary regime in March 1954 witnessed greater involvement of the state in the economy and the launching of public infrastructural projects to meet the socioeconomic needs of the country. However, despite some advances, the Syrian economy continued to be inflicted by structural weaknesses.

An analysis of Za'im's brief tenure shows that he endeavoured to implement social and economic reforms, undertake large-scale development projects and bring some prosperity to an independent Syria. Achievements in these fields could help him prolong and legitimise his regime and perhaps pave the way for the formation of a loyal constituency. To accomplish these aims, search for external resources became an integral part of his foreign 
policy. Significantly, Za'im did not hesitate to come to terms with the interests of Western oil companies that were supported by their respective governments and the neighbouring oil-rich Arab states that sought to increase their own revenues. Another controversial move by $\mathrm{Za}$ 'im, the ratification of the French-Syrian monetary agreement that settled the outstanding monetary issues with the former mandatory power, had an enduring value of giving Syria the freedom to exercise the right of legislating in monetary matters. The discrepancy between the general unfavourable attitude towards the monetary and the pipeline agreements at the time of their conclusion and their rather advantageous long-term effects points to the perils of any facile or deterministic theorising.

Displaying a strong commitment to economic development Shishakli never abandoned the search for foreign aid, even if he moved reluctantly and put leadership maintenance first.

The murder of $\mathrm{Za}^{\prime} \mathrm{im}$ by his opponents and charges of treason levelled against him must have played a considerable role in Shishakli's cautious approach to foreign aid that was perceived to be coming with political strings or encroaching on Syrian sovereignty.

Indeed, suspicion of foreign aid and concern about strings attached or anxiety over meddling in internal affairs transcended ideological and political boundaries during the period covered by the present study. With regard to the pre-union period, Western economic and technical assistance was predominantly perceived to have a high potential to encroach on Syrian sovereignty. Thus Point IV aid and World Bank loans were rejected because their sizes were considered insufficient and their terms were regarded as undermining traditional notions of sovereignty and hindering independent policy implementation. Moreover, Shishakli had to shelve his offer of a political settlement with Israel and the settling of Palestinian refugees in Syria as he failed to defuse intense domestic opposition to such an accord.

While Za'im and Shishakli sought to procure foreign financial aid and technical assistance in order to achieve a breakthrough in economic development, the People's Party which became the dominant political force in the aftermath of the coup led by Hinnawi was inclined to sacrifice Syria's independence and support unity with Iraq. While the moves to open the way for unity with Iraq led to the formation of a counter political coalition and were eventually brought to an end by a military coup, Shishakli's failure to implement his peace proposal that rested on the settlement of Palestinian refugees in Syria testifies that statesociety relations and the related question of regime autonomy have to be taken seriously especially in precarious and unconsolidated authoritarian regimes. In these respect, it is notable that although Shishakli emerged as Syria's 'strong man' after his coups, he could not overcome intense domestic opposition to a peace plan that was equated with capitulation to Western imperialism and submission to Israel even if it would have helped bridge the structural gap between the country's earning capacity and the amounts required to meet longterm investment needs. Therefore, the failure of the People's Party to bring about Syria's union with Iraq and Shishakli's failure to implement his peace proposal as well as the 
underlying reasons behind both projects point to the significance of inside-out explanations that integrate political processes of a state and its socio-economic structure.

\section{References}

Abu Jaber \& S. Kamel (1966), The Arab Ba'th Socialist Party: History, Ideology and Organisation, New York: Syracuse.

Allouni, A. (1959), "The Labor Movement in Syria”, Middle East Journal, 13(1), 64-76.

Al-'Azm, K. (1973), Mudhakkirat Khalid al-'Azm [The Memoirs of Khalid al-'Azm], 3 Volumes, Beirut: Dar al-muttahida.

Al-'Ammari, M. (1964), “al-Taniya al-iqtisadiyya al-ijtima'iyya fi suriya” [Socio-economic Development in Syria], Dirasat 'arabiyya, 1(1), 29-45.

Al-Hawrani, A. (2000), MudhakkiratAkram al-Hawrani [The Memoirs of Akram al-Hawrani], 4 Volumes, Cairo: Madbuli.

Al-Mu'allim, W. (1985), Suriya, 1918-1958, al-tahaddiwa-al-muwajaha [Syria, 1918-1958, The Challenge and the Encounter], Damascus: Sharika babel li-1-nasher.

'Arafat, 'A.H. \& N.D. Malik (1996), "al-Siyasat al-naqdiya fi suriya” [Monetary Policies in Syria], in: 'Ali Tawfiq al-Sadik et al. (eds.), al-Siyasat al-naqdiya fi al-duwal al-'arabiya [Monetary Policies in the Arab States], (Abu Dabi, United Arab Emirates: Arab Monetary Fund, The Institute of Economic Policies).

Arslan, 'A. (1994), Mudhakkirat al-Amir 'AdilArslan, 1946-1950, [Memoirs of 'AdilArslan] ed. by Yusuf Ibish, 3 Volumes (Beirut: Dar al-Taqaddumiyya).

Asfour, E. (1959), Development and Monetary Policy: Syria, Cambridge: Harvard University Press.

Babarinde, O.A. (1999), "Regionalism and African Foreign Policies", in: Stephen Wright (ed.), African Foreign Policies, Oxford: Westview Press.

Barakat, A. (1954), "Recent Economic Development in Syria", Middle East Economic Papers, 1-25.

Barnett, M.N. (1990), "High Politics is Low Politics: The Domestic and Systemic Sources of Israeli Security Policy, 1967-1977”, World Politics, 42(4), 529-562.

Barnett, M.N. (1998), Dialogues in Arab Politics, New York: Columbia UniversityPress.

Batatu, H. (1978), The Old Social Classes and the Revolutionary Movements of Iraq, Princeton: Princeton University Press.

Be'eri, E. (1970), Army Officers in Arab Politics and Society, Pall Mall: Praeger.

Brand, L.A. (1995), Jordan's Inter-Arab Relations. The Political Economy of Alliance Making, New York: Columbia University Press.

Carleton, A. (1950), “The Syrian Coups d'État of 1949”, Middle East Journal, 4(1), 1-11.

Çatı, M.O. (2013), “The political economy of Syrian foreign policy: 1949-1963", unpublished PhD Dissertation, SOAS, University of London.

Dabbagh, S.M. (1962), "Agrarian Reform in Syria”, Middle East Economic Papers, 1-15.

Didier, R. (1949), "Le maréchal Husni el Zaim nous expose son programme”, Gazette de Lausanne, 1 July 1949.

Ehteshami, Penetrated Regional System, London: Routledge. 
Fansa, N. (1982), AyyamHusni al- Za'im: 137 Yawmanhazzatsuriyya [Days of Husni al- Za'im: 137 Days Shook up Syria], Beirut: Dar al-Afaq al-Jadidah.

Franck, D.S. (1949), “The Middle East Economy in 1948”, Middle East Journal, 3, 201-210.

Gardiner, A.Z. (1950), "Point Four and the Arab World, An American View", Middle East Journal, 4(3), 296-306.

Hakim, G. (1950), "Point Four and the Middle East: A Middle East View", Middle East Journal, 4(2), 183-195.

Holden, D. \& R. Johns (1981), The House of Saud, London: Pan Books.

Hill, C. (1977), “Theories of Foreign Policy Making for the Developing Countries”, in: Christopher Clapham and William Wallace (eds.), Foreign Policy Making in Developing States, Westmead, London: Saxon House.

Hinnebusch, R.A. (1989), Authoritarian Power and State Formation in Ba'thist Syria. Army, Party and Peasant, Westview Press, Boulder.

Hinnebusch, R.A. \& N. Quilliam (2006), "Contrary Siblings: Syria, Jordan and the Iraq War", Cambridge Review of International Affairs, 19(3), 513-528.

Hudson, M.C. (1977), Arab Politics; The Search for Legitimacy, New Haven: Yale University Press.

Hudson, V.M. (2005), "Foreign Policy Analysis: A Factor Specific Theory and the Ground of International Relations", Foreign Policy Analysis, 1, 1-30.

International Bank for Reconstruction and Development (1955), The Economic Development of Syria, Baltimore: The Johns Hopkins University Press.

Jabbur, G. (1993), al-Fikr al-siyasi al-mu'asir fi suriya [Contemporary Arab Thought in Syria], Second Edition, Beirut: al-Manara.

Kayali, N. (1951), "Syria- A Political Study (1920-1950)", Unpublished Ph.D. Dissertation, Columbia University.

Khouri, F.J. (1963), "Friction and Conflict on the Israeli-Syrian Front", Middle East Journal, 17(1), 14-34.

Khouri, F.J. (1966), "The Policy of Retaliation in Arab-Israeli Relations", Middle East Journal, 20(4), 435-455.

Khoury, P.S. (1987), Syria and the French Mandate. The Politics of Arab Nationalism, 1920-1945, New Jersey: Princeton University Press.

Korany, B. (1990), “Analyzing Third-World Foreign Policies: A Critique and a Reordered Research Agenda", in: David Wurfel and Bruce Burton (eds.), The Political Economy of Foreign Policy in Southeast Asia, New York: St. Martin's Press.

Korany, B. \& A.E.H. Dessouki (1991), “A Literature Survey and a Framework for Analysis”, in: Bahgat Korany \& Ali E. Hillal Dessouki (eds.), The Foreign Policies of Arab States, Second Edition, Oxford: Westview.

Landis, J. (2001), “Early U.S. Policy toward Palestinian Refugees: the Syria Option”, in: Joseph Ginat and Edward J. Perkins, (eds.), The Palestinian Refugees: Old Problems - New Solutions, University of Oklahoma Press: Norman, OK.

Lawson, F.H. (2007), "Syria's Relations with Iran: Managing the Dilemmas of Alliance”, Middle East Journal, 61(1), 29-47. 
Lesch, D.W. (1990), “The United States and Syria, 1953-1957: The Cold War in the Middle East”, Ph.D. Dissertation, Harvard University. Lesch's dissertation was published in 1992:

David Lesch, "Syria and the United States: Eisenhower's Cold War in the Middle East" (Boulder: Westview, 1992).

Levy, J.S. \& M.M. Barnett (1992), “Alliance Formation, Domestic Political Economy, and Third World Security”, The Jerusalem Journal of International Relations, 14(4), 19-40.

Little, D. (1990), “Cold War and Covert Action: The United States and Syria, 1945-1958”, Middle East Journal, 44(1), 51-75.

Light, M. (1994), "Foreign Policy Analysis", in: A.J.R Groom and Margot Light, (eds.), Contemporary International Relations: A Guide to Theory, London: Pinter.

Macfarlane, N.S. (1999), "Taking Stock. The Third World and the End of the Cold War", in: Louise Fawcett and Yezid Sayigh (eds.), The Third World beyond the Cold War. Continuity and Change, Oxford: Oxford University Press.

Makdisi, S. (1961), “Some Aspects of Syrian Economic Growth 1945-1957”, Middle East Economic Papers, 45-63.

Mayall, J. (1990), Nationalism and International Society, Cambridge: Cambridge University Press.

Ma'oz, M. (1995), Syria and Israel. From War to Peace-making, Oxford: Clarendon Press.

Morgenthau, H.J. (1993), Politics among Nations: The Struggle for Power and Peace, Revised by Kenneth W. Thomson, New York: McGraw-Hill.

Morphet, S. (2004), "Multilateralism and the Non-Aligned Movement: What is the Global South Doing and Where It Is Going?", Global Governance, 10, 517-537.

Mufti, M. (1996), Sovereign Creations: Pan-Arabism and Political Order in Syria and Iraq, Ithaca and London: Cornell University Press.

Pappé, I. (1992), The Making of the Arab-Israeli Conflict 1947-1951, London: I.B. Tauris.

Perthes, V. (1995), The Political Economy of Syria Under Asad, London: I.B. Tauris.

Petran, T. (1972), Syria: A Modern History, London, Ernest Benn Limited.

Rabinovich, I. (1991), The Road Not Taken, Early Arab-Israeli Negotiations, Oxford, Oxford University Press.

Ro'i, Y. (1974), From Encroachment to Involvement. A Documentary Study of Soviet Policy in the Middle East: 1945-1973, New York and Toronto: John Wiley and Sons.

Rose, G. (1998), "Neoclassical Realism and Theories of Foreign Policy”, World Politics, 51(1), 144172.

Sadowski, Y.M. (1984), "Political Power and Economic Organisation in Syria: The Course of State Intervention, 1946-1958", Unpublished Ph.D. Dissertation, University of California.

Seale, P. (1986), The Struggle for Syria: A Study of Post-War Arab Politics 1945-1958, Second Edition, London: I. B. Tauris.

Salloukh, B.F. (2009), 'Demystifying Syrian Foreign Policy under Bashar al-Asad', in: Fred H. Lawson (ed.), Demystifying Syria, London: Saqi with the London Middle East Institute of SOAS.

Salmore, B.G. \& S.A. Salmore (1978), "Political Regimes and Foreign Policy", in: M. East, S. A. Salmore, and C. F. Hermann (eds.), Why Nations Act: Theoretical Perspectives for Comparative Foreign Policy Studies, London: Sage Publications. 
Sayigh, Y.A. (1978), The Economies of the Arab World: Development Since 1945, London: Croom Helm.

Seale, P. (1986), The Struggle for Syria: A Study of Post-War Arab Politics 1945-1958, Second Edition, London: I. B. Tauris.

Seurat, M. (1980), "Les populations, l'état et la société", in : André Raymond (ed.), La Syrie d'aujourd'hui, Paris: CNRS.

Shlaim, A. (1986), "Husni Za'im and the Plan to Resettle Palestinian Refugees in Syria", Journal of Palestine Studies, 15, 68-80.

Smith, S. (1987), "Foreign Policy Analysis and International Relations", Millennium: Journal of International Studies, 16(2), 345-348.

Smith, M. (1989), "Comparing Foreign Policy Systems: Problems, Processes and Performance”, in: Michael Clarke and Brian White (eds.), Understanding Foreign Policy: The Foreign Policy System Approach, Hants: Edward Elgar.

Spero, J.E. \& J.A. Hart (2003), The Politics of International Economic Relations, Sixth Edition London: Thomson.

Syrian Arab Republic, Central Bureau of Statistics, Statistical Abstract, (Damascus, Government Press, various issues [annual publication]).

Taliaferro, J.W. (2009), "Neoclassical Realism and Resource Extraction: State Building for Future War”, in: Steven E. Lobell, Norris M. Ripsman and Jeffrey W. Taliaferro (eds.), Neoclassical Realism, the State, and Foreign Policy, Cambridge, New York: Cambridge University Press.

Uphapp, N.T. \& W.F. Ilchman (1972), The Political Economy of Development, Theoretical and Empirical Contributions, London: University of California Press.

United Nations (1954), Yearbook of the United Nations 1954, New York: Department of Public Information.

Van Dusen, M.H. (1971), "Intra-and Inter-Generational Conflict in the Syrian Army", Unpublished Ph.D. Dissertation, The Johns Hopkins University.

Waltz, K.N. (1979), Theory of International Politics, New York: McGraw-Hill.

Waterbury, J. (1983), The Egypt of Nasser and Sadat. The Political Economy of Two Regimes, Princeton: Princeton University Press.

Weinstein, F.B. (1972), "The Uses of Foreign Policy of Indonesia: An Approach to the Analysis of Foreign Policy in the Less Developed Countries", World Politics, 24(3), 356-381.

Wurfel, D. \& B. Burton (1990), "The Comparative Analysis of Foreign Policy: Some Notes on the Pitfalls and Paths to Theory", in: David Wurfel and Bruce Burton (eds.), The Political Economy of Foreign Policy in Southeast Asia, New York: St. Martin's Press.

Zaffiro, J. (1999), "Exceptionality in External Affairs: Bostwana in the African and Global Arenas", in: Stephen Wright (ed.), African Foreign Policies, Oxford: Westview Press.

Zakaria, F. (1998), From Wealth to Power. The Unusual Origins of America's World Role, Princeton: Princeton University Press.

Ziadeh, N.A. (1957), Syria and Lebanon, London: Ernest Benn Limited. 
Çatı, M.O. (2016), "Economic Development and Foreign Policy, The Case of Syria 1949-1954", Sosyoekonomi, Vol. 24(27), 183-209. 